Article

\title{
Implementing the New Urban Agenda in Rwanda: Nation-Wide Public Space Initiatives
}

\author{
Ilija Gubic * and Oana Baloi \\ Global Green Growth Institute, Kigali, Rwanda; E-Mails: ilija.gubic@gggi.org (I.G.), oana.baloi@gggi.org (O.B.) \\ * Corresponding author
}

Submitted: 31 January 2019 | Accepted: 4 March 2019 | Published: 30 June 2019

\begin{abstract}
Rwanda, with its population of $12,600,000$, growing $2.8 \%$ yearly, and significant investments in infrastructure and construction in its capital Kigali and six secondary cities identified as economic poles of growth, aims to achieve a 35\% urbanisation rate by 2024. Kigali and Rwanda's secondary cities are currently revising their master plans in response to the pressure of rapid urban growth in infrastructure and services. To address the lack of public spaces in its cities, the Ministry of Infrastructure, the Rwanda Housing Authority, local authorities, the Global Green Growth Institute, and other stakeholders have committed to deliver a range of activities in this area. Their commitments include the assessment of public spaces, which will be used as a baseline for the purpose of reporting on the Sustainable Development Goals public space indicators (11.7) and further revision of the master plans of Rwanda's secondary cities. This article firstly builds on the existing knowledge and understanding of public spaces in Rwanda's planning documents, followed by an examination of how multiple actors in Rwanda interact in order to promote a nation-wide public space agenda. The main findings indicate emerging forms of innovative collaboration and partnerships for public spaces involving all levels of the Rwandan government, development partners, the civil society sector, and other stakeholders. The article concludes that, as planning documents and strategies on public spaces are in place and in line with the recommendations of the New Urban Agenda, given the limited budget for its development, Rwanda needs access to innovative funding sources in order to effectively implement public space initiatives across the country.
\end{abstract}

\section{Keywords}

climate change; master plan; New Urban Agenda; public space; Rwanda; secondary city; Sustainable Development Goals; urban design; urban planning

\section{Issue}

This article is part of the issue "Public Space in the New Urban Agenda: Research into Implementation", edited by Michael W. Mehaffy (KTH Royal Institute of Technology, Sweden), Tigran Haas (KTH Royal Institute of Technology, Sweden), and Peter Elmlund (Axel and Margaret Ax:son Johnson Foundation, Sweden).

(C) 2019 by the authors; licensee Cogitatio (Lisbon, Portugal). This article is licensed under a Creative Commons Attribution 4.0 International License (CC BY).

\section{Introduction}

For more than two decades, Africa has been the world's most rapidly urbanising region, with $40.4 \%$ of its population now in cities. Within Africa, while East Africa is still the least urbanised sub-region, its annual rate of urban growth of $4.17 \%$ is very high, with Rwanda among the fastest urbanising countries at $4.5 \%$. Two decades ago, Burundi and Rwanda were the least urbanised countries in East Africa with just $7.2 \%$ and $9.8 \%$ of the population living in urban areas, respectively (UNDESA, 2018). While Burundi has remained the least urbanised country in East Africa, Rwanda is poised to become one of the region's most urbanised countries if it achieves its urbanisation target of $35 \%$ by 2024 . In East Africa, the main driver of urban growth is the natural increase of the population (Fox, 2017), together with growth from rural to urban migration: cities, therefore, need to ensure that their in- 
creasing number of residents are adequately housed and their basic needs met, but also that they are engaged in supporting their city's prosperity.

Against this backdrop of rapid urban growth, public spaces are a key element in ensuring social cohesion (Peters, Elands, \& Buijs, 2010) and wellbeing in East Africa's cities, with wide-ranging benefits to security (Nail \& Erazo, 2018), public health (Cicea \& Pirlogea, 2011; Hoffimann, Barros, \& Ribeiro, 2017), the environment (Rakhshandehroo, Tahir, Yusof, \& Yunos, 2017), and others. While research on public spaces and the increasing threat posed by unplanned urbanisation is already well developed in Kenya (Makworo \& Mireri, 2011), elsewhere in East Africa, in-depth studies on public space in cities are limited. This may be explained by the general interest of research institutions and development partners in the provision of basic services such as electricity, water supply, and waste management, while public spaces may still be regarded more as a commodity in least developed countries.

In this context, most work on public spaces in East Africa is led by the United Nations (UN) and other development partners. For example, the UN Human Settlements Programme (UN-Habitat) is promoting the participation of youth, women, and girls in the design of public spaces to improve urban security: in Kalobeyei Town, Kenya, it partnered with women's groups to install lighting in areas identified as unsafe by focus groups. Across the world, research has shown that crime rates drop significantly with public investment in public spaces (Kondo, 2016). The importance of public spaces for development is also demonstrated by numerous other initiatives by UN agencies, from gender-sensitive design to improve women's safety by the UN Entity for Gender Equality and the Empowerment of Women (UN Women) and shared community resources by Food and Agriculture Organization (FAO), to healthy green space by World Health Organization (WHO) and hubs for creativity and innovation by the World Bank. This reflects an increasing focus on public spaces following the adoption of the Sustainable Development Goals (SDGs) in 2015 and the celebration, that same year, of "Public Spaces for All" as the theme for World Habitat Day (UN, 2015), with then Secretary-General of the UN Ban Ki-Moon reminding governments and stakeholders that "public spaces can also provide basic services, enhance connectivity, boost economic activity, and raise property values while generating municipal revenues. Successful public spaces do not just happen; they require careful collaboration among local authorities, local inhabitants, and other actors" (UN Web TV, 2015).

\section{Public Spaces in Development Agendas}

The adoption by UN Member States of Agenda 2030 in September 2015 was a major milestone: for the first time there was clear recognition from the international community of the need to focus on sustainable urban- isation, with SDG 11, "make cities and human settlements inclusive, safe, resilient and sustainable", dedicated to this aim. This included a specific provision on public space (SDG 11.7): "By 2030, provide universal access to safe, inclusive and accessible, green and public spaces, in particular for women and children, older persons and persons with disabilities" (UN General Assembly, 2017). A number of targets under SDG 11, as well as other SDGs, are linked to functional, well planned and designed public spaces to ensure urban development responds to climate change and promotes safety, inclusivity, and public health. The following year, countries across the world adopted the New Urban Agenda (NUA) during the UN Conference on Housing and Sustainable Urban Development (Habitat III) in October 2016 in Quito, Ecuador. The NUA was the culmination of three years of preparation involving a wide range of governments, observers, and stakeholders, with public spaces identified as one of the main priority areas (Habitat III Secretariat, 2016). The Habitat III process generated a compendium of summary documents and recommendations on the most pressing urban issues (Zivanovic Milic \& Trkulja, 2017), including an issue paper prepared by UN-Habitat with contributions from UN Women and the Secretariat of the Convention on Biological Diversity (CBD) on public spaces (Habitat III Secretariat, 2017). During the preparatory process, Barcelona's local authority hosted a thematic meeting on public spaces: this resulted in the Barcelona Declaration, calling on governments to include public spaces in the NUA (UN General Assembly, 2016). The Barcelona Declaration also calls for the democratic co-production of urban space, for all inhabitants, whether temporary or permanent. There was also a great deal of momentum from local authorities, civil society groups and other stakeholders in shaping inputs on public spaces for the NUA not discussed here. These initiatives helped shape the final text of the NUA, with its emphasis on promoting safe, inclusive, accessible, green and quality public spaces. The NUA mentions public spaces in paragraphs 36, 97, 99, and 109 through the lens of urban sustainability and as stand-alone commitments in paragraphs $13,37,53,67$, and 100 . It is important to ensure adequate means of implementation and a sound monitoring framework to catalyse action on public space (Andersson, 2016).

\section{Research Questions and Methods}

This article, drawing on research on public spaces in Rwanda's six secondary cities-Huye, Muhanga, Musanze, Nyagatare, Rubavu, and Rusizi-examines whether current initiatives are embedded in a collaborative planning framework that meaningfully incorporates interaction among different stakeholders. It explores three questions around the issue of public spaces in Rwanda: 1) How does Rwanda's current approach to urban planning reflect concerns around public space issues, and do they align with NUA recommendations? 
2) How are emerging partnerships on public spaces in Rwanda managing to raise awareness of the benefits of public spaces to all actors in the urban sector nationwide? 3) To what extent do government decision makers and Rwanda's development partners prioritise public space initiatives? Firstly, a literature review and analysis of Rwanda's planning documents were conducted in order to understand the general context of urban development in the country and to what extent the existing national legislation addresses public spaces. Secondly, to present an in-depth understanding of the current trends in public spaces in Rwanda, field visits were conducted in Rwanda's six secondary cities to assess their public spaces. For this research, the authors chose the secondary city of Nyagatare as a case study. Thirdly, the authors drew on the results of more than 1,000 surveys with citizens of the secondary cities, as well as more than 10 semi-structured interviews with government officials from the Ministry of Infrastructure, the Rwanda Housing Authority, and other public institutions.

\section{The NUA Implementation in Rwanda: Focus on Public Spaces}

During the Habitat III Process, the Government of Rwanda presented their Habitat III National Report (NR). Given that more than $40 \%$ of member states did not submit Habitat III NRs or organise National Committees, as advised by the UN, this indicated a clear interest from the Government of Rwanda in localising the NUA. Habitat III NRs are seen as a baseline for monitoring and evaluating the NUA implementation. The only analysis of public spaces in the Habitat III NR prepared by the Government of Rwanda, however, was through a discussion of a safer cities project run by one of the contributing stakeholders, the Rwanda Women's Network (RWN). After the adoption of the NUA in October 2016, the Government of Rwanda undertook a review of its existing laws and policies against the NUA as part of the Rwanda State of the Environmental Outlook, prepared by the Rwanda Environment Management Authority (REMA) with support from the Ministry of Infrastructure and other stakeholders (REMA, 2017), though so far, no policies have actually been revised to localise the NUA. In this respect, the NUA should be seen as an additional tool for the operationalisation of the adopted legal and policy framework, but also for the design and implementation of other spatial and urban planning documents to be prepared and adopted in the future (Zivanovic Milic \& Trkulja, 2017).

Nevertheless, the Government of Rwanda has taken a positive step through the organisation by the Ministry of Infrastructure of the National Urban Forum (NUF), a multi-stakeholder platform to support sustainable urban development by promoting awareness raising, participation, coordination, engagement, and discussion in this area. For the NUF's "Implementing the New Urban Agenda", a number of stakeholders including the World Bank, the Global Green Growth Institute, the Interna- tional Growth Centre (IGC), and UN-Habitat, led by the Ministry of Infrastructure, prepared a background paper on Government of Rwanda's work to date on various urbanisation issues, including public spaces, with projects in Rubavu public beach and Mount Rubavu highlighted as notable achievements in this area. The report also mentioned an on-going assessment of public spaces in Nyagatare, Huye, and Rubavu (Ministry of Infrastructure, 2019) that will be presented as a case study in this article. Other initiatives, also held as parallel events to the NUF, included Urban Walk and Inclusive Cities Talk, organised by the Global Green Growth Institute, all linked to the importance of public spaces and the inclusion of residents in their planning, design and implementation, as suggested in paragraph 97 of the NUA. During the NUF, emphasis was also placed on how to mobilise financial resources and fully localise the global urban development agenda, as well as enhancing capacities through the exchange of best practices.

\section{Public Space in Rwanda's Planning Documents}

In the Vision 2020 and Vision 2050 blueprints, an emphasis is placed on developing basic infrastructure in urban centres to enable the decongestion of agricultural zones, investment in job creation, and service provision to ensure a good quality of life. The latter anticipates that the proportion of Rwandans living in cities and towns will increase to $35 \%$ by 2024 and has as its main goal the transformation of Rwanda's agriculturebased economy to industry and services. Following the 2nd Economic Development and Poverty Reduction Strategy 2013-2018 (Ministry of Finance and Economic Planning, 2013), which focused on urbanisation and the promotion of six secondary cities as poles of economic growth, Rwanda (currently classified as a low-income country) initiated the 1st National Strategy for Transformation 2018-2024 (NST 1; Ministry of Finance and Economic Planning, 2018) as a first step to achieve its objective of becoming a low middle-income country by 2024, middle-income country by 2035, and high-income country by 2050. Rwanda refers to World Bank's classifications of economies according to gross national income (GNI) per capita, whereby low income is \$995 or less; lower middle income \$996-3,895; upper middle income $\$ 3,896-12,055$; and high income $\$ 12,056$ or more. All countries bordering Rwanda-Burundi, Democratic Republic of Congo, Tanzania, and Uganda-are also lowincome economies. Urbanisation is identified as one of the main ways to achieve this transformation in Rwanda. To implement the urban component of NST 1, the Government of Rwanda, through the Ministry of Infrastructure, has elaborated the Urbanization and Rural Settlement Sector Strategic Plan 2018-2024. The Government of Rwanda also adopted the National Urbanization Policy (NUP) in December 2015: this emphasises urbanisation as an engine of economic development and sustainable growth. 


\subsection{Provision of Public Space in Rwanda's Urban Legislation}

The main legislation regulating urbanisation is the Law Governing Urban Planning and Building in Rwanda of 2012 and its implementing orders of 2015. Local physical development is regulated based on clear procedures. Master plans are guided by the National Land Use and Development Master Plan of 2010 which provides the general directives and principles for land use development including densification, mixed land use, mixed housing, green design, and participation. Unfortunately, of the above-mentioned policies, laws, and district development strategies (DDSs), only a few documents define public spaces specifically.

In Rwanda National Land Use Planning Guidelines "public spaces are all places publicly owned or of public use, accessible and enjoyable by all for free and without profit motive" (Ministry of Natural Resources, 2017). According to that definition, it would be hard to identify such spaces since access is often restricted or fully prohibited, especially in green open spaces. Socially vulnerable groups create a very high demand for urban green public spaces (Rahman \& Zhang, 2018). Furthermore, paragraph 100 of the NUA recommends well-designed networks of safe, accessible, green, and quality streets and other public spaces that are accessible to all. In Rwanda, most sidewalks, markets, and similar areas may be considered as public spaces freely accessible to all. Rwanda Building Code does not define public space uses specifically but refers to "recreational land use" (Ministry of Infrastructure, 2015a). In that document, recreational land use "includes public open space, greenways and green areas, recreation and sports facilities. It can be distinguished between spaces for passive recreation and spaces for active recreation" (Ministry of Infrastructure, 2015a). Related to recreation, outdoor gyms may be built in an open public space to promote structured physical activity: these are increasingly seen as an important strategy to realise public health agendas (Hoffimann et al., 2017; Lee, Loo, \& Ho, 2018).

The National Land Policy stated that green spaces, as well as valleys, would be protected, and suggests that the creation of parks and protection of existing green areas in urban zones could eventually be transformed into accessible open public spaces (Ministry of Lands, Environment, Forests, Water and Mines, 2004). The policy also presents a general framework for the future urban development of Rwanda, with reference to public space: "Rwanda's urban agenda encourages multi-institutional cooperation for the development of safe public space, quality education, medical and transport facilities, and a friendly city ambience offering public services and infrastructure" (Ministry of Infrastructure, 2015b). The Rwanda National Land Use Planning Guidelines have also set guidelines for the promotion, protection and creation of public, open and green spaces in Rwanda (Ministry of Natural Resources, 2017). The Guidelines stipulate that "open spaces, natural beauty, and environmentally sensitive areas should be maintained and developed for financial value" (Ministry of Natural Resources, 2017). Financial value of public spaces is discussed in paragraph 53 of the NUA as a commitment to:

Promote safe, inclusive, accessible, green, and quality public spaces as drivers of social and economic development, in order to sustainably leverage their potential to generate increased social and economic value, including property value, and to facilitate business and public and private investments and livelihood opportunities for all. (UN, 2016)

The document, in conformity with the Urban Planning Code (UPC), states that small neighbourhood parks should provide access to basic public space functions. This context is determined by the needs and behaviour of users, but also by land ownership, design, and the impact of the public space on the city-wide system of open spaces (Harteveld, 2017). The UPC serves as the basis for the sustainable development and management of land use for human settlements in Rwanda: for instance, it recommends that at least five\% of urban residential areas should be allocated to public spaces and facilities and provides recommended standards on the widths of sidewalks when designing intra-urban roads (Ministry of Infrastructure, 2015c).

In the upgrading and renewal of urban informal settlement, the guidelines stipulate that in conformity with Ministerial Order no. 04/Cab.M/015 of 18/05/2015 determining urban planning and building regulations and the Rwanda UPC, trees, green areas and spaces should be preserved and restored. Paragraph 97 of the NUA calls for the provision of public spaces in the upgrading of slums and informal settlements (UN, 2016). Furthermore, article 46 of the Organic Law no. 04/2005 of 08/04/2005, determining the modalities of protection, conservation, and promotion of the environment in Rwanda, calls for the government and citizens to "establish, maintain, and manage parklands and green spaces". The same law elsewhere calls for clean public spaces. Ministerial Order no. 04/Cab.M/015 of 18/05/2015, determining urban planning and building regulations in Rwanda in articles 3, 5 and 14 calls for "quality public space and greening" in urban planning. Green public spaces could offer a wide range of activities and features, functioning as local landmarks and connecting to pedestrianised zones where possible. The Order also determines various public space typologies: these are numerous and include public parks, communal gardens (Nikolaidou, Kloti, Tappert, \& Drilling, 2016), public spaces associated with public buildings and others (Sandalack \& Alaniz Uribe, 2010), and are aimed to be evenly distributed throughout urban residential areas, sport related spaces, and others (Johnson \& Glover, 2013).

Another planning document is the Green Growth and Climate Resilience National Strategy for Climate 
Change and Low Carbon Development. Designed to support Rwanda's development into a climate-resilient, lowcarbon economy by 2050, the strategy suggests favouring the creation of high-density, walkable cities to avoid excessive sprawl and long commuting times. The strategy also recommends corridors for pedestrians and cyclists, and green public spaces to improve the population's quality of life (Government of Rwanda, 2011). Such wording aligns with paragraph 118 of the NUA, calling for the provision of adequate pedestrian and $\mathrm{cy}$ cling infrastructure. The national strategy also calls for urban areas that are attractive with trees, parks, and public spaces to promote low-carbon transport, improve quality of life, and reduce the risk of flooding (Government of Rwanda, 2011). The experiences of other countries regarding flood prevention measures, where investments can be four times more cost-effective than post-disaster reconstruction (Lochhead, 2017; Silva \& Costa, 2018), highlight the importance of public spaces and resilient development in Rwanda, given the climateinduced challenges already evident in the country, particularly droughts and floods.

The Ministry of Infrastructure, with the Global Green Growth Institute, developed the National Roadmap for Green Secondary City Development (NRGSCD; Ministry of Infrastructure \& Global Green Growth Institute, 2016). Since the six cities are experiencing similar urban problems to those observed in Kigali, the Government of Rwanda deems that planning for the growth of those cities in a sustainable framework will increase benefits and avoid negative consequences such as urban sprawl, traffic congestion, the growth of informal settlements, and inadequate public services. To support green urban development in the six secondary cities, the authors of the NRGSCD recommend that they increase financial resources and local revenues to support investment in improved public spaces: these would, in turn, generate more public income. However, since public investment is solely addressed to priorities other than public space, the need for external resource allocation could be explored to ensure public spaces are developed in Rwanda's secondary cities.

In the absence of a clear definition of "public spaces" in the Rwandan context, different terms, though they do not have the same meaning, are used interchangeably in different governmental publications to mean "public spaces". This inconsistency in the definition of public spaces, evident in various documents at a national level, is also found in documents related to the planning and development of public spaces in the six secondary cities of Rwanda. This results in an uneven interpretation of what constitutes public space across government departments and impedes the delivery of such services. Laws and regulations need to be reviewed to create an enabling regulatory environment to create, revitalise, manage, and maintain public space, including participatory processes to define their use and manage access to public spaces (Andersson, 2016). To overcome the lack of clarity, the Ministry of Infrastructure, the Rwanda Housing Authority, Global Green Growth Institute, and the University of Rwanda are working on a review of existing laws and policies to support the development of a common and localised understanding of public space.

\subsection{District Development Strategies Recognising Public Spaces as Development Priorities}

DDSs 2018-2024 are layout guidance for Rwanda's 30 districts to achieve their development vision and objectives, Vision 2020 and Vision 2050, emphasising strategic interventions to implement the current NST 1. DDSs were the result of a year-long consultation process reviewing what remained from the 2013-2018 District Development Plan and developing new strategic interventions. While for 24 Rwandan districts the Ministry of Local Government (MINALOC) hired consultants to facilitate discussions and draft strategies, in Rwanda's six secondary cities, Global Green Growth Institute seconded its technical district assistants to facilitate discussions. During the facilitation process with stakeholders, public spaces were identified as one of a number of important socio-economic public assets (Table 1). While there are on-going initiatives on public spaces in Musanze, their DDS does not reflect these as stand-alone commitments. With regards to economic transformation, the Musanze DDS identifies the limited green public spaces available as a weakness and proposes a $40 \%$ allocation of green space in real estate developments to meet this shortfall. To support the implementation of strategies, the Ministry of Infrastructure and the Rwanda Housing Authority have included public spaces as part of the yearly performance contract. The government-led mainstreaming of public spaces in the six secondary cities and districts is part of efforts to improve the response of cities to challenges induced by rapid urbanisation and implement the country's transformational strategy NST1.

\section{Initiatives by the Government of Rwanda Addressing Public Spaces}

A number of initiatives related to urbanisation are being implemented by the Government of Rwanda through the Ministry of Infrastructure and other line ministries and agencies. Currently, such initiatives are the Review of City of Kigali and secondary cities master plans, implementation of smart transport systems, elaboration of local urban development plans for emerging urban centres, promotion of car-free zones, and implementation of early warning systems, among others. Through the Rwanda Housing Authority, the Ministry of Infrastructure is supporting the implementation of concepts for green and smart cities and villages. A number of policy and action programmes related to urban infrastructure and construction are being implemented with support from multilateral partners and organisations, in particular regarding the upgrade of infrastructure to re- 
Table 1. Provision of public space in DDSs 2018-2024 for six secondary cities.

\begin{tabular}{|c|c|c|c|c|}
\hline $\begin{array}{l}\text { Secondary } \\
\text { Cities }\end{array}$ & $\begin{array}{l}\text { NST-1 Pillar } \\
\text { NST-1 Priority Area }\end{array}$ & NST-1 Outcome & DDS Outputs & $\begin{array}{l}\text { DDS Strategic } \\
\text { Interventions }\end{array}$ \\
\hline Nyagatare & $\begin{array}{l}\text { 1.4: Accelerate Sustainable } \\
\text { Urbanisation from } 17.3 \% \\
\text { (2013-2014) to } 35 \% \\
\text { by } 2024 .\end{array}$ & $\begin{array}{l}\text { 1.4.1: Increased } \\
\text { economic } \\
\text { opportunities and } \\
\text { social facilities. }\end{array}$ & $\begin{array}{l}\text { 54: Six green open spaces } \\
\text { developed in cities } \\
\text { emerging centres and } \\
\text { schools. }\end{array}$ & $\begin{array}{l}\text { Green open spaces } \\
\text { developed emerging } \\
\text { centres and schools. }\end{array}$ \\
\hline Huye & $\begin{array}{l}\text { 1.2: Accelerate Sustainable } \\
\text { Urbanisation from } 17.3 \% \\
\text { ( } 2013-2014 \text { ) to } 35 \% \\
\text { by } 2024 \text {. }\end{array}$ & $\begin{array}{l}\text { 1.2.1: Developed } \\
\text { and integrated } \\
\text { urban and rural } \\
\text { settlements. }\end{array}$ & $\begin{array}{l}\text { 6: Basic infrastructure } \\
\text { developed. }\end{array}$ & $\begin{array}{l}\text { Green urban public } \\
\text { spaces established. }\end{array}$ \\
\hline Rubavu & $\begin{array}{l}\text { 1.2: Accelerate Sustainable } \\
\text { Urbanisation from } 17.3 \% \\
\text { ( } 2013-2014 \text { ) to } 35 \% \\
\text { by } 2024 \text {. }\end{array}$ & $\begin{array}{l}\text { 2.1: Develop } \\
\text { flagship } \\
\text { projects in a } \\
\text { secondary city. }\end{array}$ & $\begin{array}{l}\text { 2.1.1: Flagship projects } \\
\text { developed in Rubavu City. }\end{array}$ & $\begin{array}{l}\text { Public open space } \\
\text { created. }\end{array}$ \\
\hline Muhanga & $\begin{array}{l}\text { 1.2: Accelerate Sustainable } \\
\text { Urbanisation from } 17.3 \% \\
\text { (2013-2014) to } 35 \% \\
\text { by } 2024 .\end{array}$ & $\begin{array}{l}\text { 1.2.1: Developed } \\
\text { and integrated } \\
\text { urban and rural } \\
\text { settlements. }\end{array}$ & $\begin{array}{l}\text { Livable, well-serviced, } \\
\text { connected, compact, green } \\
\text { and productive urban and } \\
\text { rural settlements with } \\
\text { a cultural identity. }\end{array}$ & $\begin{array}{l}\text { 1.2., 2.3: Green open } \\
\text { public spaces established. }\end{array}$ \\
\hline Musanze & N.A. & N.A. & N.A. & N.A. \\
\hline Rusizi & $\begin{array}{l}\text { 1.2: Accelerate Sustainable } \\
\text { Urbanisation from } 17.3 \% \\
\text { (2013-2014) to } 35 \% \\
\text { by } 2024 .\end{array}$ & $\begin{array}{l}\text { 1.2.2: Increased } \\
\text { economic } \\
\text { opportunities in } \\
\text { urban areas. }\end{array}$ & $\begin{array}{l}\text { 1.2.2.6: } 5 \text { hectares of Kivu } \\
\text { lake shores developed, } \\
\text { two stadia and one } \\
\text { gymnasium constructed } \\
\text { to serve for recreation } \\
\text { and leisure. }\end{array}$ & $\begin{array}{l}\text { Development of one } \\
\text { hectare of lake shores } \\
\text { (public gardens). } \\
\text { Development of beach to } \\
\text { provide recreational and } \\
\text { leisure facilities. }\end{array}$ \\
\hline
\end{tabular}

spond to challenges induced by rapid urbanisation and climate change. The Government of Rwanda's initiatives, or those supported by it, promote new forms of cooperation between the national, district, and city governments, development partners, civil society, women's and youth groups also used to create a new approach to urban planning and the governance of public spaces.

\subsection{Master Plans Revision}

The Global Green Growth Institute has worked in collaboration with the Government of Rwanda to develop the Green Climate Fund (GCF) Readiness Proposal for the Republic of Rwanda to access global funding for climate action. This readiness programme will strengthen the National Determined Authority's coordination capacity to align on-going climate finance efforts with green city and sustainable infrastructure development, through stakeholder engagement. The project objective is to improve collaboration and programme development in directing financing opportunities for green city development. For example, it will provide a detailed physical plan of secondary cities, incorporating low emission and sustainable development strategies in line with national policies. Public space is one component of these much-needed resilience frameworks, contributing not only to climate change adaptation and disaster risk prevention but also bringing socio-economic, physical and psychological benefits to urban residents in a context of densification and growth. As an output, these physical plans will create an enabling environment for public and private investment in climate change adaptation and mitigation at the city level. The assessment of public spaces in six secondary cities undertaken by the Ministry of Infrastructure, the Rwanda Housing Authority, Global Green Growth Institute and University of Rwanda informed the revision of the existing master plans for these secondary cities.

\subsection{Sector Working Group}

The government-led Sector Working Groups aim to improve the coordination of programme development and delivery across multiple government institutions and organisations. The Sector Working Group on urbanisation and rural settlements is led by the urbanisation division of the Ministry of Infrastructure and World Bank. Members of the Sector Working Group are other line ministries and government agencies including other stakeholders such as UN-Habitat, Global Green Growth Institute, RWN, the University of Rwanda, and others. One of four thematic sub-sector working groups is focusing on urbanization and public space, co-chaired by the Ministry 
of Infrastructure and Global Green Growth Institute. The first meeting of the thematic sub-sector working group was held in October 2018 to ensure the programmes of actions were aligned to the national priorities and commitments, as well as the identified priority areas for urban development (Ministry of Infrastructure, 2018). The thematic sub-sector working group on urbanization and public space is an important step in mainstreaming the needs and opportunities for public space in Kigali and secondary cities.

\subsection{Car Free Zone}

The City of Kigali has designated a "car-free zone" in the city centre to reduce greenhouse gas emission levels and encourage greater use of public space. However, the redesign of the road to accommodate this was not fully implemented due to a lack of allocated funds, and the car-free zone is used mainly for weekend markets and other irregular events. The City of Kigali is also promoting car-free zones in other neighbourhoods in a bi-monthly event, inviting urban dwellers to spend time outside for events such as sports activities, exhibitions, and performances. The initiative is to be replicated in other cities in Rwanda to promote public space and non-motorised transportation options.

\subsection{Importance of Public Space: Advocacy, Outreach, and Communications}

Innovative events such as Urban Walk, Inclusive Cities Talk, Urban Cinema and others aim to engage general and expert communities in the importance of public spaces through participation and consultation in its planning, design, and implementation. While at first events were organised as "pilot events", they have now been institutionalised by being incorporated into the Ministry of Infrastructure's performance contract for 2019-2020.

\subsubsection{Urban Walk: Know Your Public Spaces}

Urban Walks, an initiative piloted by Global Green Growth Institute, is organized in Kigali and Rwanda's six secondary cities with the intention of highlighting pressing urban issues to residents (Global Green Growth Institute, 2018a). One of the Urban Walks, themed around urban forests, routed participants through green areas of Rwanda's secondary city Nyagatare, where organisers explained how forestry can support the city by providing environmental services such as air and water purification, wind and noise filtering, micro-climate stabilisation, managing storm water, storing carbon (i.e., removing atmospheric carbon dioxide), and promoting urban biodiversity (Figure 1).

The Urban Walks also provided information to citizens on how urban forests contribute in many other ways to quality of city life: as attractive sources of shelter and shade, with aesthetic qualities that increase property values and therefore tax revenues too. With well-considered planning and design, urban forests in Nyagatare could be transformed into public spaces hosting recreational and leisure activities. Access to public open space is important to increase recreational walking: while this is commonly referenced in high-income

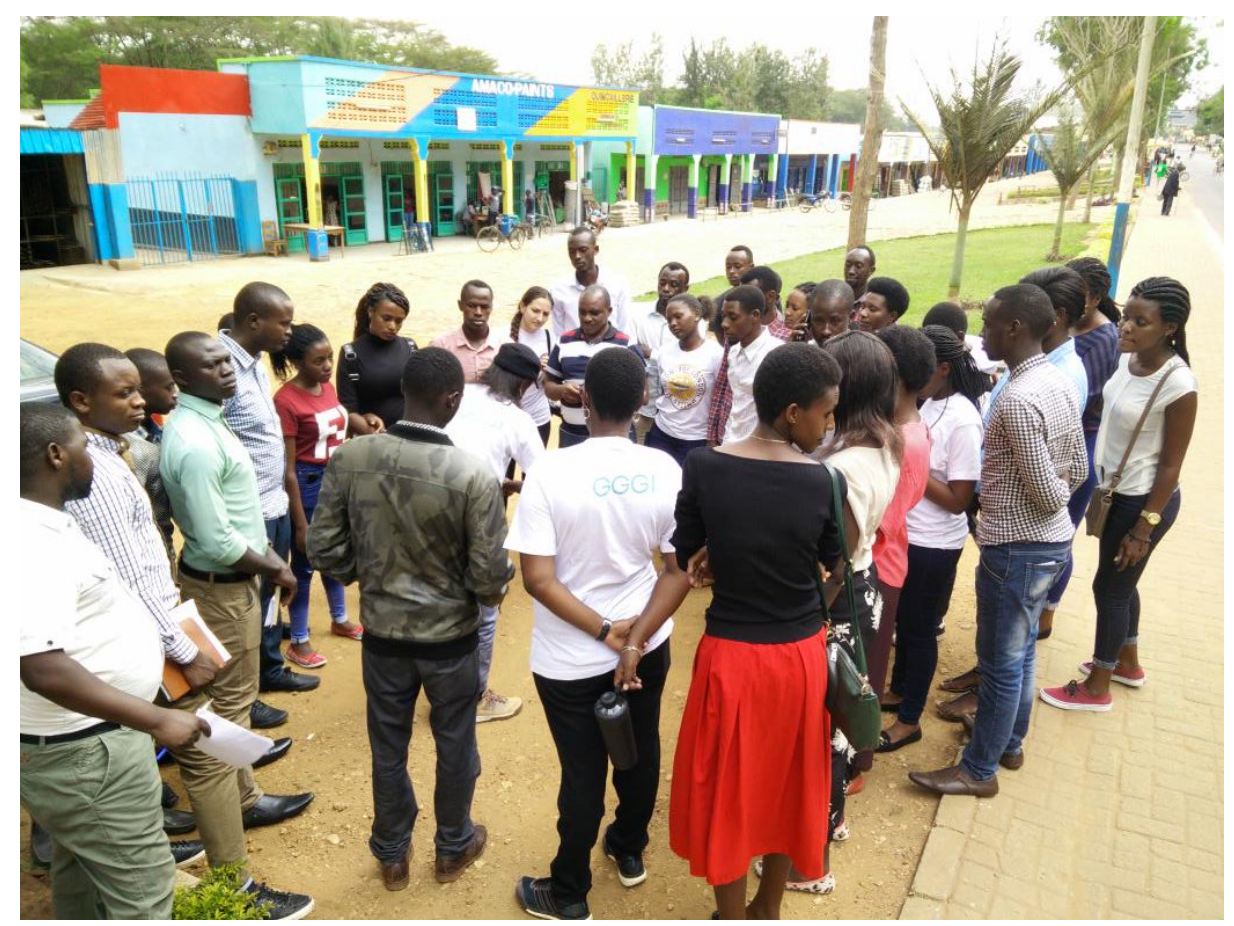

Figure 1. Urban Walk in Nyagatare. The District's Executive Secretary joined citizens in exploring green areas in the urban core, in October 2018. 
countries, there is little mention of this in middle-income and least developed countries (Florindo, Vizeu-Barrozo, Cabral-Miranda, \& Quieroti-Rodriques, 2017), hence the value of engaging citizens through this form of activity. The Urban Walks were also organized in Kigali, where Global Green Growth Institute with the University of Rwanda introduced participants to the historic business district and the public space in front of Kigali City Hall.

\subsubsection{Inclusive Cities Talk: Cities for All}

The Inclusive Cities Talk, another initiative by Global Green Growth Institute, aims to mainstream social inclusion into urban development. Through keynote sessions, dialogues, and related programmes, the focus is on public space that is safe, inclusive, and accessible. Talks are set up to discuss issues related to women and children, the elderly, and persons with disabilities, living in rapidly urbanising cities in Rwanda. The Inclusive Cities Talk sessions also serve as a platform for gathering diverse urban actors and helping to identify collaborative opportunities (Global Green Growth Institute, 2018b). Speakers included the Executive Director of UN-Habitat, the Executive Director of the New York City Public Design Commission, and others who shared with participants their experiences of engaging various stakeholders and communities into the planning, design, and implementation of public spaces.

\subsubsection{Urban Cinema}

Urban Cinema is an initiative by Global Green Growth Institute and the Rwanda Film Institute, supported by the Government of Rwanda, to promote urban cinematography addressing urbanisation issues. The initiative was designed through public participation and interaction with a panel of government representatives and experts, with an audience composed of practitioners, young graduates and students of urban development, artists, private sector representatives, and the general public. The panel discussion and interaction with the audience is streamed online.

\subsubsection{Social Media}

In Rwanda, government and non-government organisations are using online platforms such as Twitter and Whatsapp to share information and receive feedback on public information and decision making. These platforms provide authorities with a virtual space to consult with citizens and on a number of occasions, government initiatives have been revised based on the feedback received online through social media. The use of smartphones is on the rise in Rwanda, and such platforms complement radio, TV shows, and community consultations. With the public space initiative in Nyagatare (Figure 2) and other plans, draft designs were shared via social media and

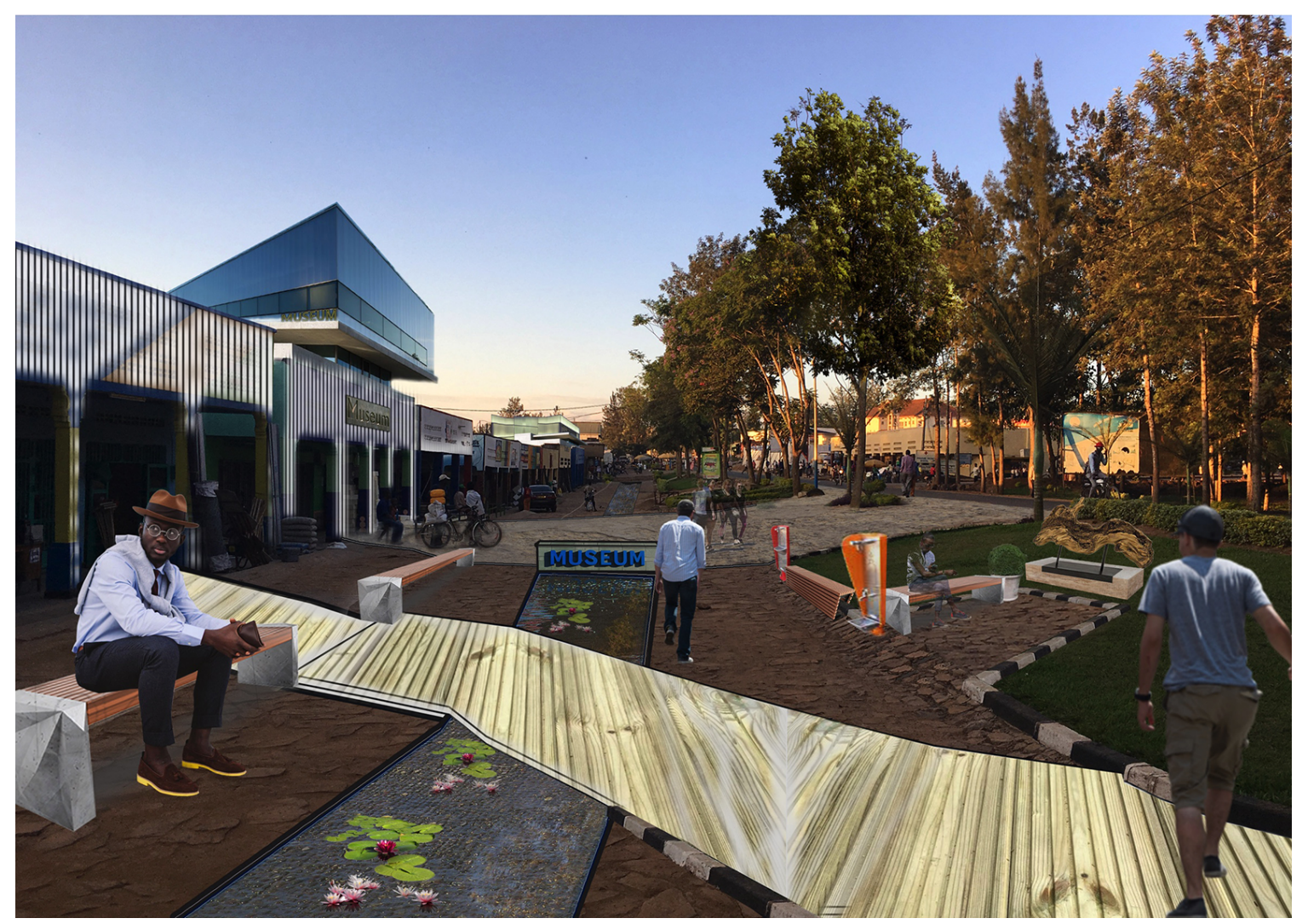

Figure 2. Photoshopped street in Nyagatare where public space elements were added, shared via social media to initiate discussion, in July 2018. 
comments from citizens were received to inform the final design of these spaces.

\section{Case Study: Nyagatare, Rwanda's Secondary City}

The Ministry of Infrastructure, the Rwanda Housing Authority, and the Global Green Growth Institute undertook citywide public space surveys in Rwanda's secondary cities of Huye, Nyagatare, and Rubavu (Figure 3) to better understand the needs of citizens for public spaces as well as what facilities and utilities these spaces should include. These surveys followed on a series of stakeholder consultations facilitated by Global Green Growth Institute in preparations for the Huye, Nyagatare, and Rubavu DDSs 2018-2024, where public spaces were identified as one of the priorities to support sustainable urbanisation. The initial survey results indicated that Huye, Nyagatare, and Rubavu residents were in favour of safe, inclusive, and accessible green and public spaces and would prefer spaces with child-friendly playground equipment and leisure facilities. The citizens are willing to walk and ride bicycles to and from public spaces and to maintain the cleanliness and functionality of these public spaces, thus contributing to their overall sustainability.

The surveys were conducted between August and November 2018. The survey was accompanied by a short training session by Global Green Growth Institute staff to surveyors with background information about the project and the types of questions that surveyors might receive. All respondents were asked if they consented to the survey before being asked the first question. The face-to-face surveys were designed to cover more than one theme and included 20 multiple choice and openended questions. There was no incentive for those who completed the survey. On average, survey response rates were above $85 \%$ of those approached in Nyagatare and Huye, and $60 \%$ in Rubavu. This is especially encouraging given that the survey was conducted with a wide range of residents including the urban poor, women, and youth, many of whom did not have access to formal education and would have had no previous knowledge or experience of public spaces benefits.

The working hypothesis of this article is that the high response rates are in large part the result of the surveys being conducted face-to-face, helped by the involvement of the RWN, an organisation widely known by residents, and an initiative being led by the Government. Overall, some variations are detected in response rates in terms of the time of day and location where surveys are conducted. Most of the surveys were conducted close to the market, school, and border crossing with the Democratic Republic of Congo in Rubavu, all of which are known for their vibrant social scene. The distribution of responses across the city is largely uniform. Some important takeaways from the study include:

- The importance of face-to-face surveys: conducting face-to-face surveys was important in building respondent trust;

- Training: delivering a short training to surveyors, who then provide information to respondents on expectations of the initiative, contributed to alleviating anxiety and made people more likely to respond;

- The lack of gender bias in response rates: the absence of any significant differences in response rates between men and women is very encouraging;

- Geographic distribution: despite some clustering in sectors located further away from the city centre, overall the geographic distribution of responses is fairly even across cities.

In addition to the survey, a technical assessment of public spaces in Rwanda's six secondary cities was undertaken to gather information on what facilities and util-

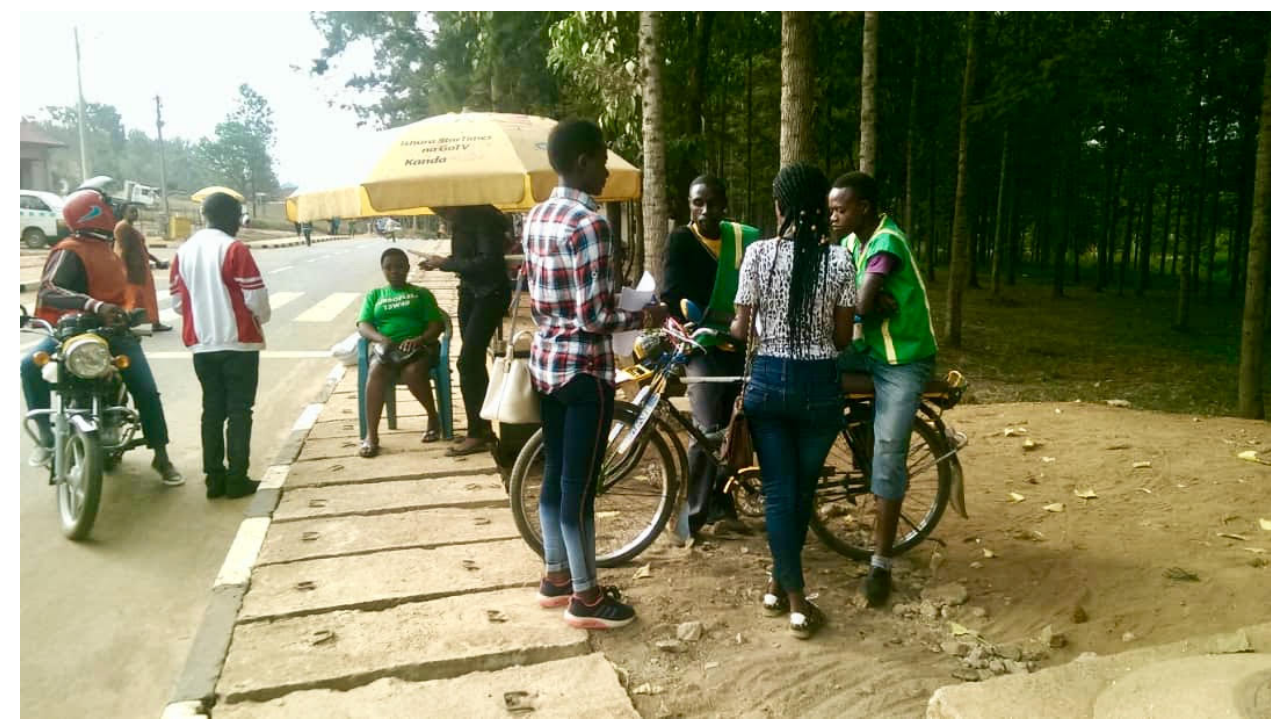

Figure 3. City-wide public space survey being conducted in Nyagatare, in August 2018. 
ities were currently available in public spaces or their surroundings to support the next steps of the planning process.

Following these processes, the city of Nyagatare (Figure 4) hosted a two-day public space participatory design workshop organised by the Ministry of Infrastructure, the Rwanda Housing Authority, and Global Green Growth Institute. Local authorities assisted with site identification by analysis of land ownership and master plan and defined the boundaries of the public space: the selected areas belong to the central government and are surrounded by public buildings and commercial areas that would benefit from well-maintained public space (Figure 5).

The main climate change impacts in Rwanda are drought and floods. In drought-prone areas similar to Nyagatare, studies show that despite the fact that properties close to well-maintained green public spaces are valued $10 \%$ higher, in times of drought irrigation of green public space is subject to restrictions (Fam et al., 2008). In Nyagatare, the area assigned for the city's public space is part of the water management system,

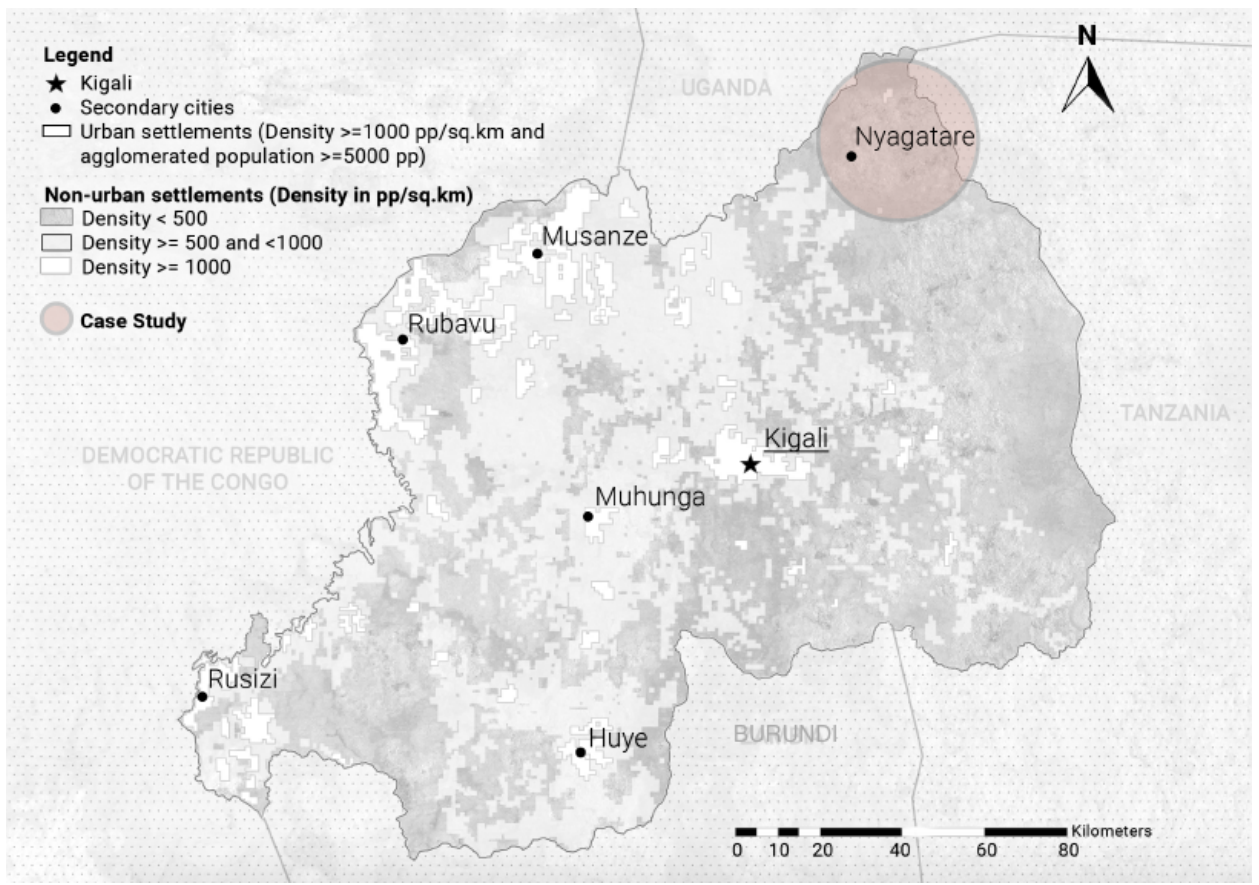

Figure 4. Location of Nyagatare within Rwanda.

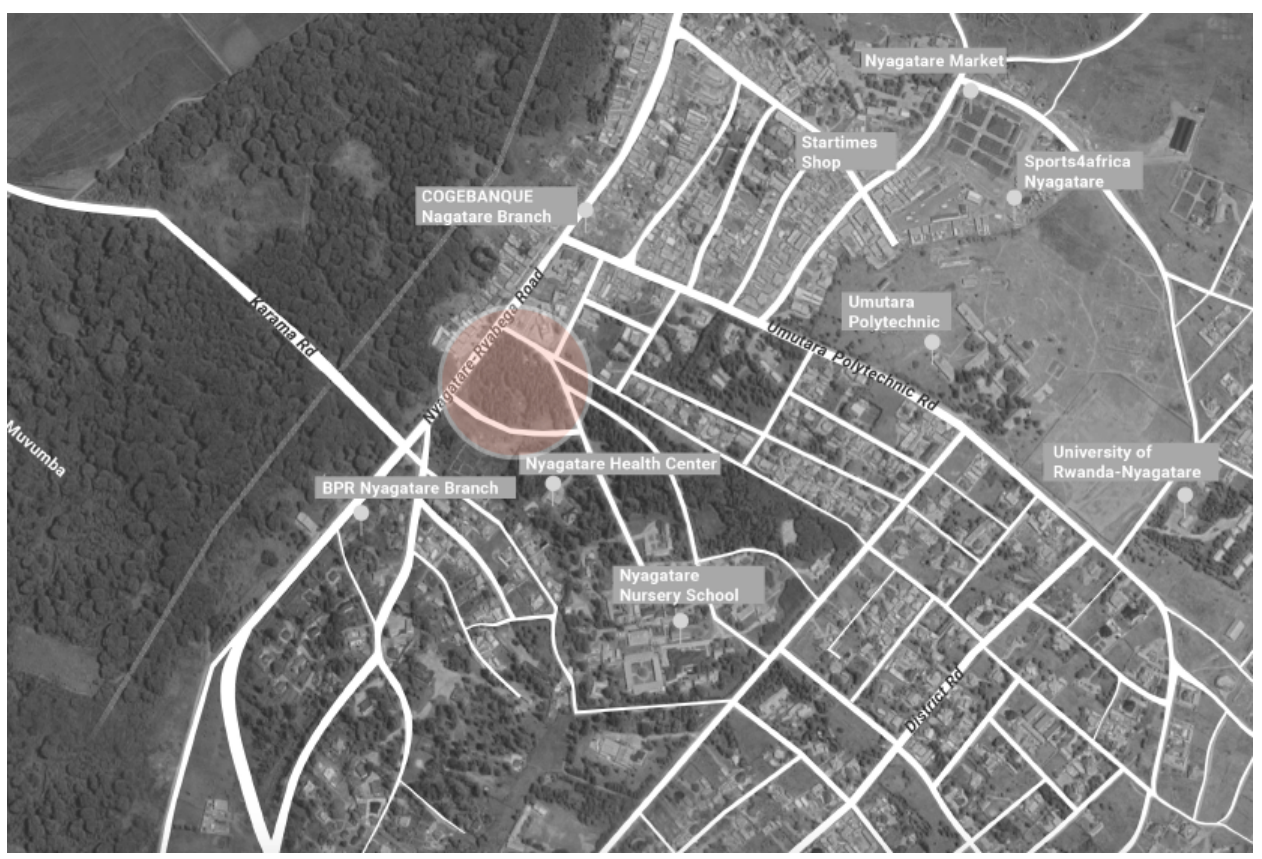

Figure 5. Location of public space within the city of Nyagatare. 
containing drains. These facilities can integrate multilayered approaches to urban systems, combining public space design with urban water management: for example, through the creation of retention ponds, the water runoff from slopes is reduced while the presence of water can be used for design purposes and for irrigation. In the context of Rwanda, where rapid urbanisation is resulting in densification, meaning reducing the residential garden size, there should be increasing availability of public gardens and open areas for both water management and public space. A study comparing "business as usual" with an innovative irrigation system showed that the use of locally sourced, untreated water was more efficient for irrigating community gardens, public parks, and recreational landscaping if the neighbourhood was designed in a water-efficient way (Dhakal, Syme, Andre, \& Sabato, 2015). In implementing Rwanda's urban agenda to enable green public spaces to add economic value to the neighbourhood, multi-institutional cooperation is required as well as water-efficient neighbourhood design.

An important concern for the current owner of the site, namely the Ministry of Agriculture, is that the intended purpose for the space was tree planting and harvesting, hence the site could be upgraded as public space as long as the design elements do not interfere with the growth of trees and production of forest material (Figure 5). Land ownership related to potential public spaces might appear to be a challenge in Rwanda, yet through collaboration, these hurdles can be overcome.

The public space design workshop in Nyagatare mobilised citizens from different backgrounds to engage in the participatory design process, with each group listing the main elements that should be incorporated in the public space to ensure they do not affect the functioning of the existent ecosystems. The participatory design included a "live" advisory session where all participants reached a consensus on where the public space design elements should be located within the site (Figure 6).

In Nyagatare, although the DDS refers to resilience in terms of agricultural production, in an urban context, the master plan revision process defines resilience in terms of actions at the household level (such as rainwater harvesting systems), in construction and building (though the promotion of green building codes), water management systems and public spaces that can be used for improving climate resilience. For example, in Nyagatare, public space, coupled with agroforestry and water management, can support water retention for longer periods and its use for community gardens and public space maintenance, important in particular during the pro-

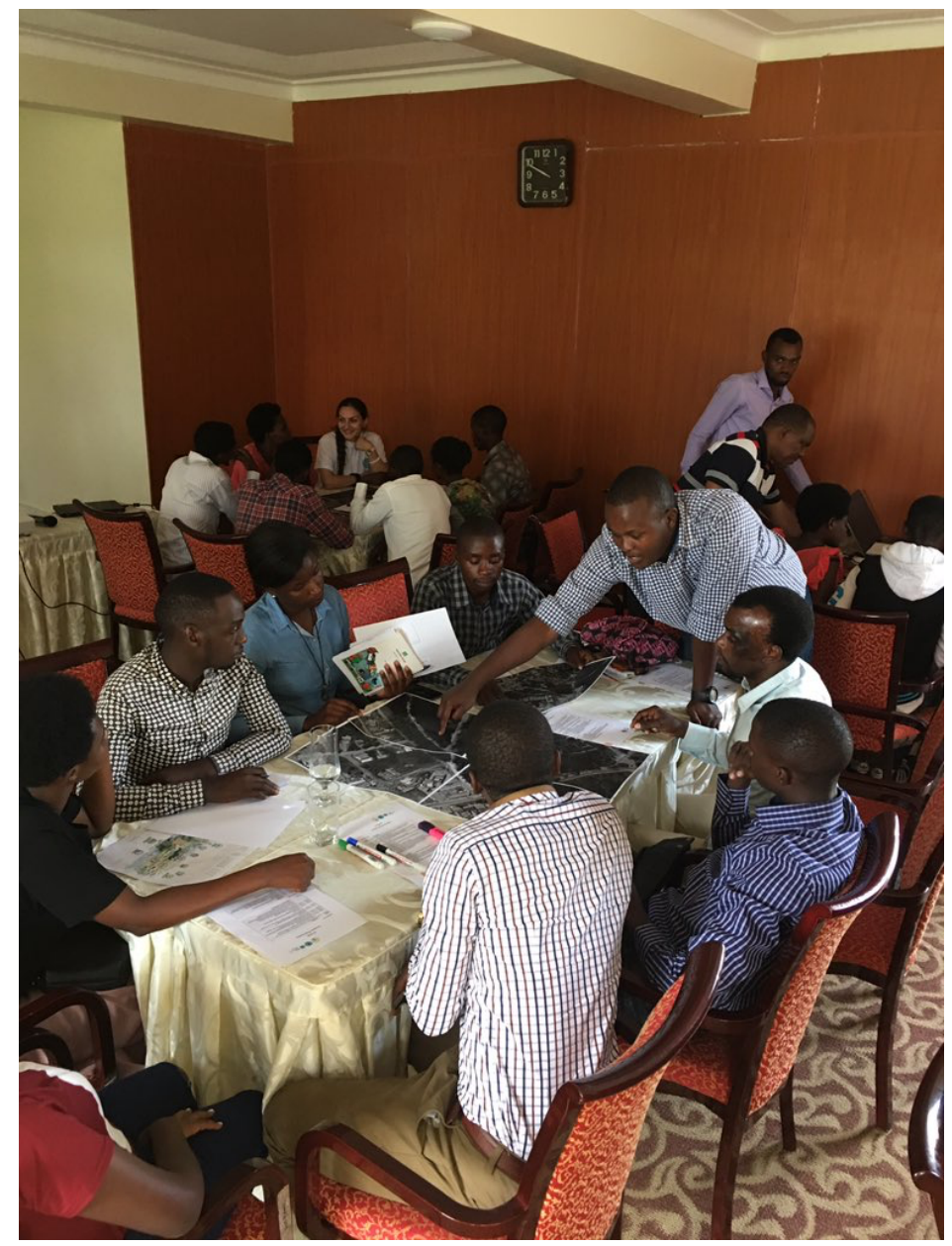

Figure 6. Public space participatory design workshop in Nyagatare, in November 2018. 
longed drought periods (Dhakal et al., 2015). The allocated site for public space is part of the proposed citywide resilience infrastructure that could include a series of open spaces (Parker \& Simpson, 2018), water and infrastructure works, and a green network linking the peri-urban ecosystems with urban green areas. While supporting increased resilience, the public spaces will also support the absorption of greenhouse gas emissions (Andriono, Hanafi, \& Yanuwiadi, 2013) and so reduce the heat island effect, improving microclimate and regulating temperatures in particular in the dry season. At the same time, this approach is promoting greater gender equality and socio-economic inclusion through safe, accessible public spaces for all.

The GCF readiness supports the implementation of the Nyagatare master plan revision and is a climaterelated intervention which also supports adequate planning and design for urban communities at risk of climateinduced disasters (Global Green Growth Institute, 2018c). Given that the government regards other types of city infrastructure as a priority, the GCF and other climate finance facilities could be considered as a means to mobilise resources for the implementation of public spaces in cities such as Nyagatare.

\section{Conclusion}

In Rwanda's current stage of rapid urbanisation, public spaces could play an important role in determining quality of life, especially as there is a trend for such spaces to be privatised and their use restricted. Although there is no clear definition of what constitutes public space in the context of Rwandan culture and development, the government's main regulatory planning documents highlight the necessity of creating and maintaining public spaces. As Rwanda is eligible to receive support from climate and other international funds, and as the government realised the role that public spaces could play in climate change adaptation and absorption of greenhouse gas emissions, there is an opportunity to collaborate with the global climate finance institutions to support development of public spaces as part of the urban resilience systems. The social benefits of public spaces in cities, on the other hand, have yet to be fully recognised by national and local authorities in Rwanda.

Despite the government's policies and initiatives, however, the development and management of public spaces fall between the mandates of different governmental entities and the Government might prefer private investment, as public space is not considered a priority for public investment. As the government's policies openly favour public spaces, the implementation of public spaces could logically be delivered through public investments since public spaces are supporting land value increase and performance of socio-economic activities. While research on public spaces in the Rwandan context is being completed, designs developed through participatory approaches and laws adopted to support their imple- mentation, what Rwanda lacks is adequate funding to realise these public spaces in practice. As a country that is still predominantly rural, with the majority of the population without access to electricity, sanitation, or clean water at the household level, its available budget is limited and generally allocated towards increasing basic services coverage rather than public space provision. Although the social, economic, and environmental benefits of public space are clear, innovative ways of funding their implementation through other means should be identified.

\section{Acknowledgments}

This research was partly conducted in the frame of the joint project on green and public spaces in Rwanda's secondary cities implemented by the Rwandan Ministry of Infrastructure, the Rwanda Housing Authority, and the Global Green Growth Institute.

\section{Conflict of Interests}

The authors declare no conflict of interest.

\section{References}

Andersson, C. (2016). Public space and the new urban agenda. The Journal of Public Space, 1(1), 5-10.

Andriono, F., Hanafi, I., \& Yanuwiadi, B. (2013). Green open space scenarios in reducing $\mathrm{CO} 2$ emissions in Malang City, Indonesia: A dynamic system approach. IOSR Journal of Engineering, 3(6), 1-13.

Cicea, C., \& Pirlogea, C. (2011). Green spaces and public health in urban areas. Theoretical and Empirical Researches in Urban Management, 6(1), 83-92.

Dhakal, R. S., Syme, G., Andre, E., \& Sabato, C. (2015). Sustainable water management for urban agriculture, gardens and public open space irrigation: A case study in Perth. Agricultural Sciences, 6, 676-685.

Fam, D., Mosley, E., Lopes, A., Mathieson, L., Morison, J., \& Connellan, G. (2008). Irrigation of urban green spaces: A review of the environmental, social and economic benefits. Cooperative Research for Irrigation Futures Technical Report (Report 04/08). Sydney: University of Western Sydney.

Florindo, A., Vizeu-Barrozo, L., Cabral-Miranda, W., \& Quieroti-Rodriques, E. (2017). Public open spaces and leisure-time walking in Brazilian adults. International Journal of Environmental Research and Public Health, 14(6), 553.

Fox, S. (2017). Mortality, migration, and rural transformation in Sub-Saharan Africa's urban transition. Journal of Demographic Economics, 83(1), 13-30.

Global Green Growth Institute. (2018a). GGGI leads "Urban Walk" in Nyagatare. Global Green Growth Institute. Retrieved from http://gggi.org/gggi-leadsurban-walk-in-nyagatare

Global Green Growth Institute. (2018b). “Inclusive Cities Talk" launched in Kigali. Global Green Growth Insti- 
tute. Retrieved from http://gggi.org/inclusive-citiestalk-launched-in-kigali

Global Green Growth Institute. (2018c). Citywide surveys on green and public spaces conducted in Huye, Nyagatare and Rubavu. Global Green Growth Institute. Retrieved from http://gggi.org/significance-ofgreen-public-space-in-cities-to-human-andenvironmental-health

Government of Rwanda. (2011). Green growth and climate resilience: National strategy for climate change and low carbon development. Kigali: Government of Rwanda.

Habitat III Secretariat. (2016). A conference of 30,000 voices. Quito: Habitat III Secretariat. Retrieved form http://habitat3.org/documents-and-archive/finalreports/30000-voices-report

Habitat III Secretariat. (2017). Habitat III issue papers. Quito: Habitat III Secretariat. Retrieved from http://habitat3.org/wp-content/uploads/HabitatIII-Issue-Papers-report.pdf

Harteveld, M. (2017). The quest for public space: Changing values in urban design, the city as learning lab and living lab. In H. Tieben, Y. Gen, \& F. Rossini (Eds), The entrepreneurial city (pp. 395-411). Rotterdam and Hong Kong: International Forum on Urbanism and the Chinese University of Hong Kong.

Hoffimann, E., Barros, H., \& Ribeiro, A. (2017). Socioeconomic inequalities in green space quality and accessibility: Evidence from a Southern European city. International Journal of Environmental Research and Public Health, 14, 916.

Johnson, A., \& Glover, T. D. (2013), Understanding urban public space in a leisure context. Leisure Sciences: An Interdisciplinary Journal, 35(2), 90-197.

Kondo, M. (2016). Effects of greening and community reuse of vacant lots on crime. Urban Studies, 53(15), 3279-3295.

Lee, J. L. C., Loo, T. L. T., \& Ho, R. T. H. (2018). Understanding outdoor gyms in public open spaces: A systematic review and integrative synthesis of qualitative and quantitative evidence. International Journal of Environmental Research and Public Health, 15, 590.

Lochhead, H. (2017). Resilience by design: Can innovative processes deliver more? Paper presented at the International High-Performance Built Environment Conference, at the Faculty of Built Environment, University of New South Wales, Australia.

Makworo, M., \& Mireri, C. (2011). Public open spaces in Nairobi City, Kenya, under threat. Journal of Environmental Planning and Management, 54(8), 1107-1123.

Ministry of Finance and Economic Planning. (2013). Economic development and poverty reduction strategy II 2013-2018. Kigali: Government of Rwanda.

Ministry of Finance and Economic Planning. (2018). 7 years government programme: National strategy for transformation (NST 1) 2017-2024. Kigali: Government of Rwanda.
Ministry of Infrastructure. (2015a). Rwanda building code. Official Gazette, 20. Retrived from https:// bpmis.gov.rw/asset_uplds/files/Rwanda\%20Building \%20Code\%20_Urban\%20Planning\%20Code.pdf

Ministry of Infrastructure. (2015b). National urbanization policy. Kigali: Government of Rwanda.

Ministry of Infrastructure. (2015c). Urban planning code. Official Gazette, 20. Retrieved from https://housingfinanceafrica.org/app/uploads/ Rwanda-Urban-Planning-Code-upc.pdf

Ministry of Infrastructure, \& Global Green Growth Institute. (2016). National roadmap for green secondary cities development. Kigali: Government of Rwanda.

Ministry of Infrastructure. (2018). Rwanda committed to fast track green and public spaces. Ministry of Infrastructure. Retrieved from http://www.mininfra.gov. rw/index.php?id=100\&L=0\&tx_news_pi1\%5Bnews $\% 5 D=131 \&$ tx_news_pi $1 \% 5 B d a y \% 5 D=6 \& t x \_n e w s \_$ pi1\%5Bmonth\%5D=9\&tx_news_pi1\%5Byear\%5D= 2018\&cHash=1f6c05fd95fe9f2298feb7c95f253a66

Ministry of Infrastructure. (2019). 3rd National urban forum, Rwanda 2019: Implementing the new urban agenda. Ministry of Infrastructure. Retrieved from http://www.mininfra.gov.rw/index.php?id=215

Ministry of Lands, Environment, Forests, Water and Mines. (2004). National land policy. Kigali: Government of Rwanda.

Ministry of Natural Resources. (2017). National land use planning guidelines. Kigali: Government of Rwanda.

Nail, S., \& Erazo, L. (2018). Waving the green flag for peace. Public spaces as peacebuilding places in colombian cities. OPERA, 22, 83-102.

Nikolaidou, S., Kloti, T., Tappert, S., \& Drilling, M. (2016). Urban gardening and green space governance: Towards new collaborative planning practices. Urban Planning, 1(1), 5-19.

Parker, J., \& Simpson, G. (2018). Visitors satisfaction with a public green infrastructure and urban nature space in Perth. Western Australia Land, 7, 159.

Peters, K., Elands, B., \& Buijs, A. (2010). Social interactions in urban parks: Stimulating social cohesion? Urban Forestry and Urban Greening, 9(2), 93-100.

Rahman, K., \& Zhang, D. (2018). Analyzing the level of accessibility of public urban green spaces to different socially vulnerable groups of people. Sustainability, 10, 3917.

Rakhshandehroo, M., Tahir, O. M., Yusof, M. J. M., \& Yunos, M. Y. M. (2017). The environmental benefits of urban open green spaces: A literature review. Management Research and Practice, 7(4), 60-71.

Rwanda Environment Management Authority. (2017). Rwanda state of environment and outlook report 2017: Achieving sustainable urbanization. Kigali: Government of Rwanda.

Sandalack, B., \& Alaniz Uribe, F. (2010). Open space typology as a framework for the public realm. Architectural Volumes, 5(2010), 35-75. Retrieved from https://www.ucalgary.ca/urbanlab/files/urbanlab/ 
Typology\%20of\%20Public\%20Space_SandalackUribe.pdf

Silva, M., \& Costa, J. P. (2018). Urban floods and climate change adaptation: The potential of public space design when accommodating natural processes. Water, 10(2). https://doi.org/10.3390/w10020180

UNDESA. (2018). World urbanization prospects: The 2018 revision. New York, NY: United Nations Department of Economic and Social Affairs.

UN General Assembly. (2016). Outcome document of the Habitat III thematic meeting on public spaces: Barcelona declaration. Barcelona: UN General Assembly. Retrieved from http://habitat3.org/ wp-content/uploads/Barcelona-Declaration.pdf

UN General Assembly. (2017). Work of the statistical commission pertaining to the 2030 agenda for sustainable development. New York, NY: UN General As- sembly. Retrived from https://undocs.org/A/RES/71/ 313

UN Web TV. (2015). Ban Ki-moon (UN SecretaryGeneral), World Habitat day 2015 (TV broadcast). UN Web TV. Retrieved from http://webtv.un.org/watch/ ban-ki-moon-un-secretary-general-world-habitatday-2015/4533216070001/?term=

United Nations. (2015). On World Habitat day, UN highlights importance of public space for all. United $\mathrm{Na}$ tions. Retrieved from https://www.un.org

United Nations. (2016). New urban agenda. New York, NY: United Nations. Retrieved form http://habitat3. org/wp-content/uploads/NUA-English.pdf

Zivanovic Milic, T., \& Trkulja, S. (2017). Serbia and the Danube area in the light of the new urban agenda. Spatium, 38, 51-58.

\section{About the Authors}
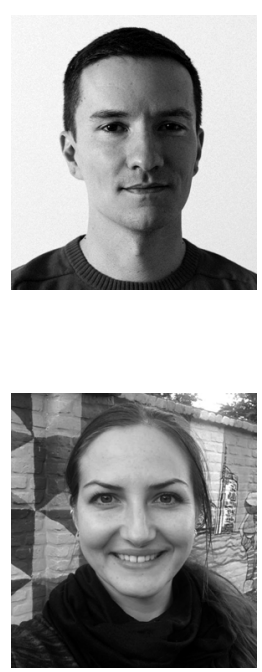

Ilija Gubic is a senior urbanisation and infrastructure officer embedded to the Rwandan Ministry of Infrastructure by the Global Green Growth Institute, working on advancing sustainable urban development of secondary cities. He is also appointed visiting assistant lecturer at the School of Architecture and Built Environment, University of Rwanda. Previously, he worked for the UN Secretariat in New York supporting the process of development of the New Urban Agenda. Prior to that, he worked for UN-Habitat, mostly in Asia and the Pacific on post-disaster processes. Ilija Gubic was a researcher at Columbia University in New York City, USA and Politecnico di Milano, Milan, Italy, and has published on urban development in least developed countries.

Oana Baloi is a landscape architect focusing on urban low emissions and resilience, currently working for the Global Green Growth Institute and implementing the Green Climate Fund readiness and preparatory support project with the Rwanda Environmental Management Authority and the Rwandan Ministry of Infrastructure. Oana Baloi has experience in working on spatial planning and public space projects in cities in East Africa with UN-Habitat, including in the crisis and post-crisis context, promoting the integration of displaced and vulnerable communities with host communities. Oana Baloi has published on cities and climate change, urban planning, and landscape architecture. 